\title{
EFFECT OF SOWING WINDOWS AND GENOTYPES ON YIELD AND ECONOMICS OF KHARIF RAJMAH
}

\author{
P. M. Chaudhari*, N. V. Kashid, D. B. Lad and V. S. Supe \\ National Agricultural Research Project, Zonal Agricultural Research Station, Pune. \\ *Corresponding Author: omrutusan@gmail.com
}

\section{ABSTRACT:}

A field study was conducted at ZARS, Ganeshkhind, Pune, Maharashtra during kharif 2017 to 2019 to identify the yield potentials of rajmah varieties at different sowing windows. Rajmah varieties viz. Phule Rajmah, HPR-35 and Varun were evaluated for yields and economics under different sowing windows viz, MW-24 (11-17 June), MW-26 (25-1 July), MW-28 (9-15 July) and MW-30 (23-29 July). Treatments were evaluated in Factorial Randomized Block Design with three replications. The soil was medium black with pH 7.65, Organic Carbon 0.45 $\%$, Available Nitrogen $220 \mathrm{~kg} / \mathrm{ha}, \mathrm{P}_{2} \mathrm{O}_{5} 17.5 \mathrm{~kg} / \mathrm{ha}$ and $\mathrm{K}_{2} \mathrm{O} 365 \mathrm{~kg} / \mathrm{ha}$. The crop was fertilized with 60:80:0 kg/ha $\mathrm{N}, \mathrm{P}_{2} \mathrm{O}_{5}$ and $\mathrm{K}_{2} \mathrm{O}$.Significantly higher seed yield (16.50, 15.79, 15.70 and $15.87 \mathrm{q} /$ ha, respectively) was recorded at harvest in sowing window $\mathrm{S}_{1}$ : MW-24 (11-17 June), while it was found at par with $\mathrm{S}_{2}$ : MW26 (25-1 July) during all the year of experiment and in pooled analysis. The genotype Phule Rajmah recorded significantly higher seed yield (14.64, 14.69 and $14.88 \mathrm{q} / \mathrm{ha}$, respectively) during year 2018 and 2019 of experimentation and in pooled analysis while found at par with Varun in 2018 and 2019. The gross return (Rs. 103155), Net returns (Rs. 57317) benefit cost ratio (2.25) was found highest in sowing window $\mathrm{S}_{1}$ : MW-24 (11-17 June) which was followed by $\mathrm{S}_{2}$ : MW26 (25-1 July) with gross returns (Rs.93275) Net returns (Rs. 47635) and benefit cost ratio (2.04). With respect to genotypes gross return (Rs.96720), Net returns (Rs. 51011) and benefit cost ratio (2.12) was found highest in Phule Rajmah which was followed by Varun (1.93B: C ratio).

\section{INTRODUCTION:}

India is the largest producer of pulses accounting for about 25 percent of the global share. Pulses are the second most important group of cropafter cereals in Jharkhand. During 2017-18 pulse was cultivated in 5.53 lakh ha. with annual production of 4,95,134 tonnes leading average productivity of $881 \mathrm{~kg}$ per ha. (Agriculture Directorate, Kharif Work shop Report, 2015-16) Pulses are least preferred by farmers because of high risk and also being less remunerative than cereals Consequently, the production of the pulses is sufficiently low it and doesn't meet the daily requirement of the growing population. The per capita per day availability of pulses has been reduced from 61g in 1951 to $32 \mathrm{~g}$ in 2000 (DES, 2004) against the minimum requirement of $60 \mathrm{~g}$ and optimum requirement of $104 \mathrm{~g}$ per day per capita. Out of different strategies to increase pulses production, the introduction of promising pulse crops such as Rajmah (Phaseolus vulgaris L.) to non-traditional areas holds on of the options.

Rajmah or french bean (Phaseolus vulgaris) is also popularly known as Rajma, haricot bean, kindey bean, snap bean, navy bean, field bean, dry bean, pole bean etc. In India, it is grown mainly in Jammu and Kashmir, Himachal Pradesh, UP and some parts of Maharastra, Andhra Pradesh, Western and Eastern Ghats and North-East plains where winter are mild and frost free as a winter crop. The growth and development of any crop is primarily governed by the environmental conditions of the soil and 
climate. The prevailing weather conditions are important for success or failure of farming. Rajmah is one of the most important pulse crops in our country which is affected by weather. Influence of different time of sowing as well as temperature on phenology and yield of crop plants can be studied under field conditions through the accumulated heat unit's system (Bishnoi et al., 1995).

Farmers can avoid some losses through simple changes of planting dates and Rajmah varietal types. Sowing time is the most critical factor for achieving higher productivity of Rajmah. Advanced or delayed sowing may cause substantial reduction in yield.

\section{RESULT AND DISCUSSION:}

The data on three years pooled results on effect of sowing windows and genotypes on kharif Rajmah are presented in Table. 1 to 4.

\section{Growth parameters:}

The data presented in Table. 1 revealed that the plant height of rajmah was significantly affected due to different sowing time during kharif 2017, 2018 and 2019. Significantly higher plant height (46.56, 39.56 and $40.11 \mathrm{~cm}$, respectively) at harvest was recorded in $\mathrm{S}_{1}$ : MW-24 (11-17 June), while it was found at par with $\mathrm{S}_{2}$ : MW26 (25-1 July) and $\mathrm{S}_{3}$ : MW-28 (9-15 July) during 2017 2018. $\mathrm{S}_{1}$ was found at par with $\mathrm{S}_{2}$ only in 2019. While in pooled analysis significantly higher plant height $(40.72 \mathrm{~cm})$ at harvest was recorded in $\mathrm{S}_{1}$ : MW-24 (11-17 June), while it was found at par with $\mathrm{S}_{2}$ : MW26 (25-1 July). Differential response of varieties to plant height might be due to their genetic character and adaptability to growing environment. Prakash and Ram (2014) were of similar opinion with respect to this trait in French bean.

Genotype HPR- 35 recorded significantly higher plant height (44.3 and $40.58 \mathrm{~cm}$, respectively) at harvest as compared to other genotypes during
2018 and 2019 and in pooled analysis. $G_{1}$ was found at par with $\mathrm{G}_{2}$ in pooled analysis. While nonsignificant result was observed in 2017.Interaction effect with respect to plant height was found nonsignificant during all the three years of experimentation and in pooled analysis.

The number of branches were not affected significantly due to different sowing windows and genotypes and their interactions during all the three years of experimentation and pooled analysis.

\section{Yield attributes and yield:}

The data presented in Table. 2 revealed that number of pods plant-1 of rajmah was significantly affected due to different sowing time during kharif 2017, 2018 and 2019 and in pooled analysis. Significantly higher number of pods plant1 (15.56, 15.22, 14.78 and 14.70 , respectively) at harvest was recorded in $\mathrm{S}_{1}$ : MW-24 (11-17 June), while it was found at par with $\mathrm{S}_{2}$ : MW26 (25-1 July) during 2018 and in pooled analysis.

Genotype Phule Rajmah recorded significantly higher number of pods plant ${ }^{-1}$ (15.58 and 15.47) at harvest as compared to other genotypes during 2018 and in pooled analysis. While nonsignificant result was observed in 2017 and 2018. The reports of Panday et al (2012) in French bean agree with the findings of present study. Interaction effect with respect to number of pods plant${ }^{1}$ was found nonsignificant during all the three years of experimentation and in pooled analysis.

The data presented in Table. 2 revealed that number of seeds pods $^{-1}$ of rajmah was significantly affected due to different sowing time during kharif 2018 and 
2019 and nonsignificant results were observed in pooled analysis. Significantly higher number of seeds pods ${ }^{-1}$ (4.56 and 4.63, respectively) at harvest was recorded in $\mathrm{S}_{1}$ : MW-24 (11-17 June), while it was found at par with $\mathrm{S}_{2}$ : MW26 (25-1 July) during both the year of experiment.

The different genotype recorded nonsignificant results in all the year of experimentation. Interaction effect with respect to number of seeds pod $^{-1}$ was found nonsignificant during all the three years of experimentation and in pooled analysis.

The data presented in Table. 3 revealed that seed yield of rajmah was significantly affected due to different sowing time during kharif 2017, 2018 and 2019 and in pooled analysis. Significantly higher seed yield $(16.50,15.79, \quad 15.70$ and 15.87, respectively) was recorded at harvest in sowing window $\mathrm{S}_{1}$ : MW-24 (11-17 June), while it was found at par with $\mathrm{S}_{2}$ : MW26 (25-1 July) during all the year of experiment and in pooled analysis.

The genotype Phule Rajmah recorded significantly higher seed yield (14.64, 14.69 and $14.88 \mathrm{q} / \mathrm{ha}$, respectively) during year 2018 and 2019 of experimentation and in pooled analysis while found at par with Varun in 2018 and 2019. Interaction effect with respect to number of seeds pod-1 was found nonsignificant during all the three years of experimentation and in pooled analysis. Among the date of sowing, first fortnight of June recorded significantly higher harvest index value closely followed by second fortnight of June, which were on par. The lower harvest index was recorded with second fortnight of July. (Mallikarjun, 2004). The results are in conformity with those reported by Venkata et al. (2015).

The data presented in Table. 3 revealed that straw yield of rajmah was significantly affected due to different sowing time during kharif2017, 2018 and 2019 and in pooled analysis. Significantly higher straw yield $(28.06,26.69,27.48$ and $27.40 \mathrm{q} / \mathrm{ha}$, respectively) was recorded at harvest in sowing window $\mathrm{S}_{1}$ : MW-24 (11-17 June) during all the year of experiment and in pooled analysis while it was found at par with $\mathrm{S}_{2}$ : MW26 (25-1 July) during 2017 and in pooled analysis.

The genotype Phule Rajmah recorded significantly higher straw yield $(27.06,24.75$, 25.71 and $25.60 \mathrm{q} /$ ha, respectively) during all the years of experimentation and in pooled analysis. While it was found at par with Varun in all three year except pooled mean. Interaction effect with respect to number of seeds pod $^{-1}$ was found nonsignificant during all the three years of experimentation and in pooled analysis.

\section{ECONOMICS:}

Pooled results presented in Table 4 revealed that the gross return (Rs.103155), Net returns (Rs. 57317) benefit cost ratio (2.25) was found highest in sowing window $\mathrm{S}_{1}$ : MW24 (11-17 June) which was followed by $\mathrm{S}_{2}$ : MW26 (25-1 July) gross returns (Rs.93275) Net returns (Rs. 47635) and benefit cost ratio (2.04).

With respect to genotypes gross return (Rs.96720), Net returns (Rs. 51011) and benefit cost ratio (2.12) was found highest in Phule Rajmah which was followed by Varun (1.93).

\section{CONCLUSION:}


Sowing of kharif Rajmah Cv. Phule Rajmah in MW-24 (11-17 June) recorded highest growth and yield attributes and seed yield and found at par results with sowing in $\mathrm{S}_{2}$ : MW26 (25-1 July). Sowing in $\mathrm{S}_{1}$ : MW-24 (11-17 June) found more remunerative followed by $\mathrm{S}_{2}$ : MW26 (25-1 July).

\section{REFERENCES:}

Bishnoi, O. P., Singh, S. and Niwas, R. 1995. Effect of temperature on development of wheat (Triticum aestivum). Indian J. Agric. Sci. 65: 211-14.

Mallikarjun, U., 2004, Performance of rajmash genotypes under different dates of sowing during kharif in the northern transitional zone of Karnataka. M.Sc. (Agri.) Thesis, University of Agricultural Sciences, Dharwad.

Pandey, Y.R., Gautam, D.M., Thapa, R.B., Sharma, M.D., and Paudyal, K.P., 2012. "Response of pole type French bean (Phaseolus vulgaris L.) genotypes to sowing dates in the mid hills of western Nepal”, Nepal Journal of Science and Technology, , volume 13(2): pp. $15-20$.

Prakash, J., and Ram, R.B., 2014. "Genetic variability, correlation and path analysis for seed yield and yield related traits in French bean (Phaseolus vulgaris L.) under Lucknow conditions", International Journal of Innovative Science, Engineering and Technology, volume 1(6): pp. 41-50.

Venkata Subbaiah Yadav B., Srinivasulu P., Reddy Syam Sundar and Balakrishna M.2015. Influence of Sowing Dates on Growth and Yield of French bean (Phaseolus vulgaris L.) Varieties under Rayalaseema Region of Andhra Pradesh) Journal of Agroecology and Natural Resource Management Volume 2, Number 2; April-June 2015 pp. 145-149

(C) Krishi Sanskriti Publications http://www.krishisanskriti.org/ janrm.html 
Table 1: Effect of sowing windows and genotypes on Plant height, Number of branches of Rajmah

\begin{tabular}{|c|c|c|c|c|c|c|c|c|}
\hline \multirow[b]{2}{*}{ Treatments } & \multicolumn{4}{|c|}{ Plant height (cm) } & \multicolumn{4}{|c|}{ Number of branches plant -1} \\
\hline & 2017 & 2018 & 2019 & $\begin{array}{c}\text { Pooled } \\
\text { Mean }\end{array}$ & 2017 & 2018 & 2019 & $\begin{array}{c}\text { Pooled } \\
\text { Mean }\end{array}$ \\
\hline \multicolumn{9}{|l|}{ A) Sowing windows (S) } \\
\hline $\begin{array}{l}S_{1}: M W-24 \text { (11-17 } \\
\text { June) }\end{array}$ & 46.56 & 39.56 & 40.11 & 40.72 & 4.00 & 5.00 & 4.44 & 4.48 \\
\hline $\begin{array}{l}S_{2}: \text { MW-26 (25 June-1 } \\
\text { July) }\end{array}$ & 43.89 & 39.44 & 39.00 & 39.81 & 3.78 & 4.78 & 4.11 & 4.22 \\
\hline$S_{3}: M W-28$ (9-15 July) & 42.00 & 37.11 & 35.89 & 37.18 & 4.22 & 4.44 & 4.22 & 4.29 \\
\hline$S_{4}: M W-30$ (23-29 July) & 37.44 & 33.33 & 34.44 & 34.38 & 4.00 & 4.22 & 3.67 & 3.96 \\
\hline SE \pm & 1.79 & 1.02 & 0.95 & 0.45 & 0.27 & 0.26 & 0.24 & 0.15 \\
\hline C.D. at $\mathbf{5 \%}$ & 5.26 & 2.99 & 2.79 & 1.29 & NS & NS & NS & NS \\
\hline \multicolumn{9}{|l|}{ B) Genotypes } \\
\hline$G_{1}:$ PhuleRajmah & 44.42 & 37.75 & 38.50 & 40.22 & 4.00 & 4.75 & 4.00 & 4.25 \\
\hline $\mathbf{G}_{2}:$ HPR-35 & 42.83 & 44.33 & 40.58 & 42.58 & 3.92 & 4.42 & 4.17 & 4.17 \\
\hline$G_{3}:$ Varun & 40.17 & 30.00 & 33.00 & 34.39 & 4.08 & 4.67 & 4.17 & 4.31 \\
\hline SEm \pm & 1.55 & 0.88 & 0.82 & 1.73 & 1.55 & 0.88 & 0.82 & 0.13 \\
\hline C.D. at 5\% & NS & 2.59 & 2.42 & 6.82 & NS & NS & NS & NS \\
\hline (A X B) Interaction & & & & & & & & \\
\hline SEm \pm & 3.11 & 1.77 & 1.65 & 0.79 & 0.46 & 0.46 & 0.42 & 0.24 \\
\hline C.D. at 5\% & NS & NS & NS & NS & NS & NS & NS & NS \\
\hline
\end{tabular}

Table 2 : Effect of sowing windows and genotypes on Number of pods plant-1 and Number of seeds pod ${ }^{-1}$ of Rajmah

\begin{tabular}{|c|c|c|c|c|c|c|c|c|}
\hline \multirow[b]{2}{*}{ Treatments } & \multicolumn{4}{|c|}{ Number of pods plant-1 } & \multicolumn{4}{|c|}{ Number of seeds pod-1 } \\
\hline & 2017 & 2018 & 2019 & $\begin{array}{l}\text { Pooled } \\
\text { Mean }\end{array}$ & 2017 & 2018 & 2019 & $\begin{array}{c}\text { Pooled } \\
\text { Mean }\end{array}$ \\
\hline \multicolumn{9}{|l|}{ A) Sowing windows (S) } \\
\hline$S_{1}:$ MW-24 (11-17 June) & 15.56 & 15.22 & 14.78 & 15.19 & 4.83 & 4.56 & 4.63 & 4.46 \\
\hline$S_{2}: M W-26$ (25 June-1 July) & 14.44 & 14.11 & 13.67 & 14.07 & 4.58 & 4.74 & 4.41 & 4.58 \\
\hline$S_{3}: M W-28$ (9-15 July) & 14.67 & 13.56 & 13.00 & 13.74 & 4.67 & 4.44 & 4.32 & 4.47 \\
\hline$S_{4}: M W-30$ (23-29 July) & 13.67 & 13.44 & 13.22 & 13.44 & 4.63 & 4.15 & 4.20 & 4.54 \\
\hline SE \pm & 0.23 & 0.37 & 0.29 & 0.17 & 0.11 & 0.08 & 0.08 & 0.06 \\
\hline C.D. at 5\% & 0.69 & 1.09 & 0.86 & 0.49 & NS & 0.22 & 0.25 & NS \\
\hline \multicolumn{9}{|l|}{ B) Genotypes } \\
\hline$G_{1}:$ PhuleRajmah & 16.08 & 15.58 & 14.75 & 15.47 & 4.72 & 4.55 & 4.37 & 4.59 \\
\hline
\end{tabular}




\begin{tabular}{|l|c|c|c|c|c|c|c|c|}
\hline $\mathbf{G}_{\mathbf{2}}$ : HPR-35 & 14.25 & 14.00 & 13.42 & 13.88 & 4.68 & 4.38 & 4.46 & 4.47 \\
\hline $\mathbf{G}_{\mathbf{3}}$ Varun & 13.42 & 12.67 & 12.83 & 12.97 & 4.63 & 4.48 & 4.35 & 4.52 \\
\hline SEm \pm & 1.55 & 0.88 & 0.82 & 0.15 & 1.55 & 0.88 & 0.82 & 0.003 \\
\hline C.D. at 5\% & $\mathrm{NS}$ & 2.59 & $\mathrm{NS}$ & 0.43 & $\mathrm{NS}$ & $\mathrm{NS}$ & $\mathrm{NS}$ & $\mathrm{NS}$ \\
\hline (A X B) Interaction & 0.41 & 0.65 & 0.51 & 0.32 & 0.19 & 0.13 & 0.14 & 0.07 \\
\hline SEm \pm & $\mathrm{NS}$ & $\mathrm{NS}$ & $\mathrm{NS}$ & $\mathrm{NS}$ & $\mathrm{NS}$ & $\mathrm{NS}$ & $\mathrm{NS}$ & $\mathrm{NS}$ \\
\hline C.D. at 5\% &
\end{tabular}

Table 3: Effect of sowing windows and genotypes on Seed and straw yield of Rajmah

\begin{tabular}{|c|c|c|c|c|c|c|c|c|c|}
\hline \multirow[b]{2}{*}{ Treatments } & \multicolumn{4}{|c|}{ Seed Yield (q/ha) } & \multirow{2}{*}{$\begin{array}{c}\% \text { yield } \\
\text { reductio } \\
n \text { over } S_{1} \\
\text { and } G_{1}\end{array}$} & \multicolumn{4}{|c|}{ Straw yield (q/ha) } \\
\hline & 2017 & 2018 & 2019 & $\begin{array}{c}\text { Pooled } \\
\text { Mean }\end{array}$ & & 2017 & 2018 & 2019 & $\begin{array}{c}\text { Pooled } \\
\text { Mean }\end{array}$ \\
\hline \multicolumn{10}{|l|}{ A) Sowing windows (S) } \\
\hline$S_{1}:$ MW-24 (11-17 June) & $\begin{array}{c}16.5 \\
0\end{array}$ & 15.79 & 15.70 & 15.87 & -- & 28.06 & 26.69 & 27.48 & 27.40 \\
\hline $\begin{array}{l}\text { S }_{2}: M W-26 \text { (25 June-1 } \\
\text { July) }\end{array}$ & $\begin{array}{c}15.2 \\
2\end{array}$ & 14.60 & 14.72 & 14.35 & 9.57 & 25.87 & 24.19 & 24.65 & 24.89 \\
\hline$S_{3}:$ MW-28 (9-15 July) & $\begin{array}{c}13.4 \\
2\end{array}$ & 12.12 & 12.52 & 12.53 & 21.04 & 22.81 & 20.49 & 21.91 & 21.73 \\
\hline$S_{4}: M W-30$ (23-29 July) & $\begin{array}{c}11.1 \\
0\end{array}$ & 10.57 & 8.59 & 9.67 & 39.06 & 18.86 & 17.87 & 15.03 & 15.92 \\
\hline SE \pm & 0.58 & 0.41 & 0.34 & 0.50 & & 0.99 & 0.69 & 0.59 & 0.74 \\
\hline C.D. at 5\% & 1.71 & 1.20 & 0.99 & 1.53 & & 2.91 & 2.04 & 1.73 & 2.57 \\
\hline \multicolumn{10}{|l|}{ B ) Genotypes } \\
\hline $\mathbf{G}_{1}:$ PhuleRajmah & $\begin{array}{c}15.9 \\
2\end{array}$ & 14.64 & 14.69 & 14.88 & -- & 27.06 & 24.75 & 25.71 & 25.60 \\
\hline$G_{2}:$ HPR-35 & $\begin{array}{c}12.3 \\
1\end{array}$ & 11.45 & 10.07 & 10.90 & 26.74 & 20.92 & 19.35 & 17.63 & 18.78 \\
\hline $\mathbf{G}_{3}:$ Varun & $\begin{array}{c}13.9 \\
5\end{array}$ & 13.51 & 13.41 & 13.53 & 9.07 & 23.72 & 22.83 & 23.46 & 23.27 \\
\hline SEm \pm & 1.55 & 0.88 & 0.82 & 0.15 & & 1.55 & 0.88 & 0.82 & 0.25 \\
\hline C.D. at 5\% & NS & 2.58 & 2.42 & 0.41 & & 4.56 & 2.59 & 2.42 & 0.71 \\
\hline \multicolumn{10}{|l|}{ (A X B) Interaction } \\
\hline SEm \pm & 1.01 & 0.71 & 0.58 & 0.81 & & 1.72 & 1.20 & 1.02 & 0.50 \\
\hline C.D. at 5\% & NS & NS & NS & NS & & NS & NS & 3.00 & NS \\
\hline
\end{tabular}


Table 4 : Economics (Pooled)

\begin{tabular}{|c|c|c|c|c|c|}
\hline Treatments & $\begin{array}{l}\text { Yield } \\
\text { (q/ha) }\end{array}$ & $\begin{array}{c}\text { Cost of } \\
\text { cultivation } \\
\text { (Rs.) }\end{array}$ & $\begin{array}{c}\text { Gross } \\
\text { monetary } \\
\text { returns } \\
\text { ( Rs.) }\end{array}$ & $\begin{array}{c}\text { Net } \\
\text { monetary } \\
\text { returns } \\
\text { ( Rs.) }\end{array}$ & B:C ratio \\
\hline \multicolumn{6}{|l|}{ A ) Sowing windows (S) } \\
\hline$S_{1}: M W-24$ (11-17 June) & 15.87 & 45837.1 & 103155 & 57317 & 2.25 \\
\hline$S_{2}:$ MW-26 (25 June-1 July) & 14.35 & 45639.5 & 93275 & 47635 & 2.04 \\
\hline$S_{3}:$ MW-28 (9-15 July) & 12.53 & 45402.9 & 81445 & 36042 & 1.79 \\
\hline$S_{4}: M W-30$ (23-29 July) & 9.67 & 45031.1 & 62855 & 17823 & 1.40 \\
\hline \multicolumn{6}{|l|}{ B ) Genotypes } \\
\hline$G_{1}:$ PhuleRajma & 14.88 & 45708.4 & 96720 & 51011 & 2.12 \\
\hline $\mathbf{G}_{2}:$ HPR-35 & 10.90 & 45191 & 70850 & 25659 & 1.57 \\
\hline $\mathbf{G}_{3}:$ Varun & 13.53 & 45532 & 87945 & 42412 & 1.93 \\
\hline
\end{tabular}

Selling rates:

2017: Rs. 6300/ qtl,

2018 :Rs. 6500/ qtl and

2019 :Rs. 6700/ qt1 